\title{
Relationship between Somatic Cell Count and Different Microbial and Chemical Quality Parameters of Bullk Tank Millk
}

\author{
El-Shaimaa N. Mehany ${ }^{1}$, Mohamed A. El-Shafaie ${ }^{1}$, Karima M. Fahim ${ }^{2 *}$,Said S. Sallam ${ }^{2}$ \\ ${ }^{1}$ Department of Mastitis and Neonates, Animal Reproduction Research Institute (ARRI); ${ }^{2}$ Department of Food \\ Hygiene and Control, Faculty of Veterinary Medicine, Cairo University, Giza 12211, Egypt.
}

\begin{abstract}
The objective of this study was to investigate bulk tank somatic cell count and associated risk factors influencing the hygienic quality and chemical composition of raw milk; additionally, to assess the impact of somatic cell count $(\mathrm{SCC} / \mathrm{ml})$ on the microbial and chemical profiles of Bulk Tank Milk (BTM). A total of 214 BTM samples were collected from different dairy farms in Alexandria, Menofia and El-Dakahlia Governorates, Egypt. Samples were collected during the period from January 2019 to September 2020. The mean values of SCC/ml, Aerobic Plate Count APC (cfu/ml), Coliform count (MPN/ml), Staphylococcus aureus count and Bacillus cereus count (cfu/ml) were $6.85 \times 10^{5} \pm 0.33 \times 10^{5}, 7.09 \times 10^{6} \pm 2.76 \times 10^{6}, 2.77 \times 10^{4} \pm 0.63 \times 10^{4}, 1.27 \times 10^{3} \pm 0.25 \times 10^{3}$ and $3.32 \times 10^{3} \pm 0.13 \times 10^{3}$, respectively. Identification of the isolated strains reveals the presence of S. aureus; coagulase negative staphylococci (CNS); St. uberis, E. coli and B. cereus with incidence of $19.16 \%, 62.15 \%, 21.50 \%, 32.24 \%$ and $10.28 \%$ of the examined BTM samples, respectively. The correlation between SCC and different bacteriological and chemical parameters was estimated using Pearson's correlation coefficient $(r)$. Most BTM samples tested for milk quality parameters were below the acceptable limits suggested by the legislations; however, food poisoning bacteria (E. coli, B. cereus and S. aureus) were isolated. Thus, there is a need to improve milking hygiene, proper herd and udder health management to improve quality and safety of raw milk.
\end{abstract}

Keywords | Bulk tank milk, Somatic cell count, Microbial quality, Safety, Milk composition

Received | March 30, 2021; Accepted | July 09, 2021; Published | August 25, 2021

*Correspondence | Karima M. Fahim, Department of Food Hygiene and Control, Faculty of Veterinary Medicine, Cairo University, Giza 12211, Egypt; Email: dr.karima_fhc@cu.edu.eg

Citation Mehany E-SN, El-Shafaie MA, Fahim KM, Sallam SS (2021). Relationship between somatic cell count and different microbial and chemical quality parameters of bulk tank milk. Adv. Anim. Vet. Sci. 9(10): 1660-1668.

DOI | http://dx.doi.org/10.17582/journal.aavs/2021/9.10.1660.1668

ISSN (Online) | 2307-8316; ISSN (Print) | 2309-3331

Copyright (C) 2021 Mehany et al. This is an open access article distributed under the Creative Commons Attribution License, which permits unrestricted use, distribution, and reproduction in any medium, provided the original work is properly cited.

\section{INTRODUCTION}

$\mathrm{M}$ ilk is a nutritious food containing many essential nutrients. This composition is changed by physiological factors including species and breed of the animal, season, feed and stage of lactation. It is also affected by the healthy status of the mammary glands and the general animal health. The largest proportion of milk produced for human consumption is obtained from cattle (Van Hooijdonk and Hettinga, 2015).

Considering the bulk tank milk (BTM) is an accurate and effective approach for evaluating the milk quality at the herd level, and it is particularly useful for the detection and identification of contagious bacteria in cows affected by subclinical mastitis (Azevedo et al., 2016). Somatic cells are normal constituents of milk that is infiltrated from the blood during lactation. Any intra-mammary infection results in influx of somatic cells, predominantly polymorphonuclear neutrophils (PMN), from the blood into the mammary gland as they serve as a part of the defense system and assist in repairing damaged tissues. Therefore, somatic cell count (SCC) is considered as an important tool for detection of subclinical mastitis (Alhussien and Dang, 2018).

The increase in milk SCC is related to changes in the milk composition. Several studies indicated reduction 
in lactose, fat and casein contents in milk in consequent of SCC elevation (Lindmark-Månsson et al., 2006). The elevation of SCC in BTM is an indicator of both raw milk quality and the prevalence of subclinical mastitis in dairy herds. Therefore, most countries set a critical limit for SCC, above which milk cannot be collected from the farm, also some milk processing plants and/or marketing cooperatives adopted more stringent quality standards to the farms and offer bonus payments as a real financial incentive to produce milk of low SCC (Olechnowicz and Jaśkowski, 2012; Alhussien and Dang, 2018).

Milk is a nutritious product and is a good medium for the growth of a wide diversity of microorganisms. The consumption of contaminated milk may lead to foodborne diseases. The most accused pathogens in outbreaks of foodborne illnesses due to consumption of raw milk and its products were $S$. aureus, E. coli especially Shiga toxinproducing one, Salmonella species, Klebsiella species, Proteus species, Yersinia enterocolitica, Campylobacter jejuni, Pseudomonas aeruginosa and Listeria monocytogenes from different countries (Sarkar, 2016).

Escherichia coli is a member of coliform group and considered as an indicator organism reflecting the hygienic quality of food and indicates direct or indirect fecal contamination. Additionally, E. coli is responsible for serious fatalities and milk borne disease outbreaks around the world (Ahmed and Fahim, 2018).

Staphylococci are normal commensals of the skin and mucosa of both healthy human and animals. They are an important agent of bovine mastitis, leading to economic losses in dairy farms. S. aureus is considered as a major public health problem, it produces many extracellular proteins and toxins which probably contribute to the virulence of this organism. Staphylococcal food poisoning is very common, the symptoms subside within $24-48 \mathrm{~h}$, but the disease may remain for 7-10 days (Mohamed et al., 2016; Fisher and Paterson, 2020).

Coagulase negative staphylococci (CNS) have appealed increasing interest as they have been isolated from mastitis in dairy animals, they adapted to survive in the bovine environment or called opportunistic pathogens, they are potential zoonotic pathogens, and they have the capability to produce enterotoxins in food (Torky and Abu Tabeikh, 2016).

Bacillus cereus is an important foodborne pathogen, which causes two distinct types of food poisoning; diarrheal and emetic type caused by two different types of toxins. Centers for Disease Control and Prevention (CDC) reported domestically acquired foodborne illness caused by B. cereus in the US, with estimated number of 63,400 cases annually (Naas et al., 2018). In addition, B. cereus has been identified as an occasional cause of bovine mastitis in New Zealand (Cressey et al., 2016).

Streptococci are considered as main human and animal pathogens include more than 40 subspecies and several groups. They continue to be a major cause of subclinical mastitis in dairy cattle, causing economic losses for the dairy industry especially St. agalactiae, St. uberis and St. dysgalactia. Streptococcal infections in human are associated with scarlet fever, bacterial endocarditis, rheumatic fever, sore throat, tonsillitis, and pneumonia (Youssef and Mohamed, 2015).

The guidelines to evaluate the BTM quality vary between studies on SCC and their effect on other milk constituents (Bi et al., 2016; Macedo et al., 2018) to the prevalence of foodborne pathogens (Youssf and Mohamed 2015; Kupradit et al., 2020); Additionally, the quality of BTM is determined through different bacterial parameters as enumeration of total aerobic bacteria, coliform and $S$. aureus in relation to SCC (Moheebi-Fani et al., 2016; Naing et al., 2019).

Therefore, the present study was conducted to evaluate the quality and safety of BTM through determination of SCC with its impact on the hygienic and chemical profiles, and the assessment of microbiological parameters (Aerobic Bacterial count, Coliform, E. coli, total staphylococci, $S$. aureus, CNS, B. cereus and Streptococci); in addition to the correlation between SCC, milk constituents and microbial parameters. The degree of acceptability of the examined bulk tank milk vs. the Egyptian and European standards was evaluated.

\section{MATERIALS AND METHODS}

\section{Collection of BTM SAMPLES}

A total of 214 BTM samples were collected from different dairy farms in Alexandria, Menofia and El-Dakahlia Governorates, Egypt. Samples were collected during the period from January 2019 to September 2020 under complete aseptic conditions as described by Jayarao and Wolfgang (2003). Collected samples were transferred to the laboratory in insulating icebox to be immediately examined for the following:

\section{Determination OF SOMATIC CELL COUNT/ML (SCC/ ML)}

The technique described by Zecconi et al. (2002) was adopted using Nucleo Counter ${ }^{\varpi}$ SCC-100 ${ }^{\mathrm{TM}}$ (Denmark, Chemometic 0613-019-061uol). 
BACTERIOLOGICAL EXAMINATION OF BTM SAMPLES

- Preparation of samples: Ten fold decimal dilutions of bulk tank milk samples were prepared according to the technique described by APHA (2004). The prepared dilutions were subjected to the following bacteriological examinations.

- Aerobic plate count (APC) $\mathrm{cfu} / \mathrm{ml}$ was carried out according to ISO (2003) using standard plate count agar (PCA) medium.

- Coliform count (MPN/ml) was adopted according to BAM (2013), using the 3 tubes technique containing Lauryl Sulphate Tryptose Broth (LSTB) (Oxoid, CM0451) and supplemented with inverted Durham's tubes.

- Isolation and identification of E. coli was determined as described by BAM (2013), using loopfuls from positive tubes of LSTB.

- Total Staphylococci count (cfu/ml) was carried out using Baird-Parker agar plates according to the technique described by BAM (2013).

- Isolation and identification of S. aureus: Representative colonies on Baird-Parker agar plates were isolated and identified according to BAM (2001).

- Bacillus cereus count (cfu/ml) was determined according to the technique recommended by BAM (2012), using mannitol egg yolk polymixin B agar (MYP) medium (Oxoid-CM0929).

- Isolation and identification of B. cereus: Representative colonies on (MYP) agar plates were isolated and identified according to Solanki et al. (2019).

- Isolation and identification of Streptococci species was determined according to Quinn et al. (2011) using Edward's agar media (HiMedia Ref. M748). Typical colonies were isolated and identified according to Whitman et al. (2009).

\section{Chemical ANALYSIS}

- $\mathrm{pH}$ value was determined as outlined by Khodke et al. (2009) using calibrated $\mathrm{pH}$-meter (Adwa-AD1030, Hungary).

- Milk constituents were determined according to APHA (2004). The Lactoscan ultrasonic milk analyzer (Bulgaria-25010) was used for determination of fat \%, protein $\%$, lactose $\%$, solids non-fat (S.N.F) \% and ash $\%$ of examined BTM samples.

- Chlorine \% was determined according to APHA (2004).

\section{STATISTICAL ANALYSIS}

The obtained data were analyzed using SPSS software statistics version 20. Pearson's correlation coefficient $(r)$ was used to evaluate correlation between milk hygiene indicators and variables of milk composition. Significance was set at $P$-value $<0.05$.

\section{RESULTS AND DISCUSSION}

\section{BULK TANK SOMATIC CELL COUNT (SCC/ML)}

The mean SCC in the examined BTM samples was $6.85 \times 10^{5}$ cells/ml, Table 1, (41.59\%) of the samples have $\mathrm{SCC}<500$ $\mathrm{X} 10^{3},(24.77 \%)$ of the samples have SCC within the range $500-750 \times 10^{3} / \mathrm{ml}$ and $(33.64 \%)$ of the samples have SCC within the range $750 \times 10^{3}->10^{6}$ (Table 2). According to the requirements of the Egyptian Specifications of raw milk (SCC not $>750 \times 10^{3}$ ) and the European specifications (SCC not $\left.>400 \times 10^{3}\right) ; 66.36 \%$ and $31.78 \%$ of the examined samples complied to both standards, respectively, (Table 4).

Table 1: Statistical analytical results of examined BTM samples based on their $\mathrm{SCC} / \mathrm{ml}$.

$\begin{array}{lllll}\text { No. of samples } & \text { Min. } & \text { Max. } & \text { Mean } & \pm \text { SEM } \\ 214 & 4.00 \times 10^{4} & 2.53 \times 10^{6} & 6.85 \times 10^{5} & 0.33 \times 10^{5}\end{array}$

Table 2: Frequency distribution of examined BTM samples based on their $\mathrm{SCC} / \mathrm{ml}$.

\begin{tabular}{llc}
$\begin{array}{l}\text { Interval } \\
\text { (cells } \mathbf{~ 1 0}\end{array} \mathbf{~}^{3} / \mathbf{m l}$ ) & No. & Positive samples \\
\hline 250 & 33 & 15.42 \\
\hline $250-500$ & 56 & 26.17 \\
\hline $500-750$ & 53 & 24.77 \\
$750-1000$ & 28 & 13.08 \\
$>1000$ & 44 & 20.56 \\
Total & 214 & 100
\end{tabular}

\section{BACTERIOLOGICAL PARAMETERS}

Aerobic mesophilic microbial count and coliform count were recorded in all examined BTM samples with mean values of $7.09 \times 10^{6} \mathrm{cfu} / \mathrm{ml}$ and $2.77 \times 10^{4} \mathrm{MPN} / \mathrm{ml}$, respectively. Staphylococcus aureus and B. cereus pathogens were detected in the examined BTM samples with mean count of $1.27 \times 10^{3}$ and $3.32 \times 10^{3} \mathrm{cfu} / \mathrm{ml}$, respectively, Table 3.

\section{BACTERIAL ISOLATION AND IDENTIFICATION}

Escherichia coli, S. aureus, Coagulase Negative Staphylococci (CNS) and B. cereus were isolated from the examined BTM samples with incidence of $32.24,19.16,62.15$ and 10.28\%. As well, $49.07 \%$ of the samples proved to be contaminated with streptococci (Table 5). On studying the degree of acceptability of the examined BTM samples conferring the requirements of the Egyptian and European standards, $82.24 \%$ and $87.85 \%$ of the samples were conforming both Specifications, respectively, regarding their content of $S$. aureus; while $89.72 \%$ of the samples were acceptable to both standards regarding their content of $B$. cereus (Table 3). 
Table 3: Statistical analytical results of examined BTM samples based on their bacteriological examination and correlation (r) with SCC.

\begin{tabular}{lllllllll} 
Parameters & $\begin{array}{l}\text { No. of examined } \\
\text { samples }\end{array}$ & \multicolumn{2}{l}{ Positive samples } & Min. & Max. & Mean & \pm SEM & $*(\mathbf{r})$ \\
APC $(\mathrm{cfu} / \mathrm{ml})$ & 214 & 214 & 100 & $1.55 \times 10^{3}$ & $9.52 \times 10^{7}$ & $7.09 \times 10^{6}$ & $2.76 \times 10^{6}$ & $0.965^{\mathrm{a}}$ \\
Coliform count $(\mathrm{MPN} / \mathrm{ml})$ & 214 & 214 & 100 & 3.00 & $1.10 \times 10^{5}$ & $2.77 \times 10^{4}$ & $0.63 \times 10^{4}$ & $0.926^{\mathrm{a}}$ \\
S. aureus count $(\mathrm{cfu} / \mathrm{ml})$ & 214 & 41 & 19.16 & 50.00 & $5.50 \times 10^{3}$ & $1.27 \times 10^{3}$ & $0.25 \times 10^{3}$ & $0.502^{\mathrm{a}}$ \\
B. cereus count $(\mathrm{cfu} / \mathrm{ml})$ & 214 & 22 & 10.28 & $9.5 \times 10^{2}$ & $7.50 \times 10^{3}$ & $3.32 \times 10^{3}$ & $0.13 \times 10^{3}$ & $0.81^{9} \mathrm{a}$
\end{tabular}

${ }^{a}$ Correlation is significant at $p$-value $<0.01, *(r)$ : Pearson's correlation coefficient.

Table 4: Acceptability of the examined BTM samples vs. the Egyptian and European Specifications, regarding their $\mathrm{SCC} / \mathrm{ml}$, S. aureus and B. cereus $\mathrm{cfu} / \mathrm{ml}$.

\begin{tabular}{|c|c|c|c|c|c|c|c|c|}
\hline \multirow[t]{3}{*}{ Parameter and Permissible limit } & \multicolumn{4}{|c|}{ Egyptian Specification (ES) } & \multicolumn{4}{|c|}{ European Specification (EUS) } \\
\hline & \multicolumn{2}{|c|}{ Accepted } & \multicolumn{2}{|c|}{ Not accepted } & \multicolumn{2}{|c|}{ Accepted } & \multicolumn{2}{|c|}{ Not accepted } \\
\hline & No. & $\%$ & No. & $\%$ & No. & $\%$ & No. & $\%$ \\
\hline $\begin{array}{l}\mathrm{SCC} / \mathrm{ml} \\
\mathrm{E} \mathrm{S}\left(<750 \times 10^{3}\right) ; \mathrm{EUS}\left(<400 \times 10^{3}\right)\end{array}$ & 142 & 66.36 & 72 & 33.64 & 68 & 31.78 & 146 & 68.22 \\
\hline $\begin{array}{l}\text { S. aureus cfu/ml } \\
\text { E S }(<100) ; \text { EUS }(<500)\end{array}$ & 176 & 82.24 & 38 & 17.76 & 188 & 87.85 & 26 & 12.15 \\
\hline $\begin{array}{l}\text { B. cereus } \mathrm{cfu} / \mathrm{ml} \\
\mathrm{E} \mathrm{S}(<1) ; \mathrm{EUS}(<10)\end{array}$ & 192 & 89.72 & 22 & 10.28 & 192 & 89.72 & 22 & 10.28 \\
\hline
\end{tabular}

Table 5: Identification of different isolated bacterial species from examined BTM samples.

\begin{tabular}{|c|c|c|c|c|c|c|}
\hline \multirow[t]{2}{*}{ Genus } & \multirow[t]{2}{*}{ No. of isolates } & \multicolumn{3}{|c|}{ Identified species } & \multicolumn{2}{|c|}{ Positive samples } \\
\hline & & Species & No. & $\%$ & No. & $\%$ \\
\hline \multirow[t]{2}{*}{ Staphylococci } & 294 & S. aureus & 51 & 17.35 & 41 & 19.16 \\
\hline & & CNS & 243 & 82.65 & 133 & 62.15 \\
\hline \multirow[t]{2}{*}{ Streptococci } & 140 & St. uberis & 51 & 36.43 & 46 & 21.50 \\
\hline & & *Other streptococci species & 89 & 63.57 & 68 & 31.78 \\
\hline Coliforms & 134 & E. coli & 114 & 85.07 & 69 & 32.24 \\
\hline Bacillus spp. & 63 & B. cereus & 63 & 100 & 22 & 10.28 \\
\hline
\end{tabular}

*Other streptococci species (are those species of streptococcus other than St. uberis, St. agalactia and St. dysgalactia).

CORRElations BETWEen SCC AND MICROBIAL PARAMETERS

The obtained results show statistically significant positive correlations between SCC and microbial parameters (Total aerobic bacteria, Coliform, S. aureus and B. cereus count), positive correlations between different bacterial groups (Total aerobic bacteria, Coliform and S. aureus), Table 3.

Chemical anAlysis of EXAMined SAMPles AND its CORRELATION TO SCC

The mean values of Fat, protein, S.N.F, Lactose, Ash, Chlorine $\%$ and $\mathrm{pH}$ of the examined bulk tank milk samples were $4.33 \pm 0.07,3.17 \pm 0.01,8.37 \pm 0.01,4.64 \pm 0.01$, $0.67 \pm 0.02, \quad 0.094 \pm 0.002$ and $6.32 \pm 0.01$, respectively. Significant weak positive correlations were detected between SCC and fat \%, and between SCC and ash \% (Table 6).

October 2021 | Volume 9 | Issue 10 | Page 1663
Table 6: Statistical analytical results of examined BTM samples based on their chemical analysis and correlation (r) with SCC.

$\begin{array}{llllll}\text { Parameter } & \text { Min. } & \text { Max. } & \text { Mean } & \pm \text { SEM } & *(\mathbf{r}) \\ \text { Fat \% } & 3.12 & 6.36 & 4.33 & 0.07 & 0.216^{\mathrm{b}} \\ \text { Protein \% } & 2.95 & 3.51 & 3.17 & 0.01 & 0.045 \\ \text { S.N.F \% } & 8.25 & 8.87 & 8.37 & 0.01 & 0.108 \\ \text { Lactose \% } & 4.31 & 5.16 & 4.64 & 0.01 & 0.024 \\ \text { Ash \% } & 0.62 & 0.76 & 0.67 & 0.02 & 0.228^{\mathrm{b}} \\ \text { Chlorine \% } & 0.060 & 0.160 & 0.094 & 0.002 & -0.173 \\ \text { pH value } & 6.20 & 6.80 & 6.32 & 0.01 & -0.055\end{array}$

${ }^{\mathrm{b}}$ Correlation is significant at $\mathrm{p}$ value $<0.05,{ }^{*}(r)$ : Pearson's correlation coefficient.

Somatic Cell count of BTM is used to determine the quality of the produced milk and to differentiate between normal and abnormal milk (Ruegg and Pantoja, 2013). 
Most of the examined BTM show high SCC (> 500 X $10^{3}$ cells $/ \mathrm{ml}$ ), which parallel to the results recorded by Gillespie et al. (2012), while higher results were recorded by Macedo et al. (2018) and Olatoye et al. (2018). Lower SCC were recorded by Moheebi-Fani et al. (2016).

The accepted limit of SCC/ml of bulk tank milk vary in different countries as from $<400 \times 10^{3}$ in European Union, Australia, New Zealand and Canada, to $<1,000,000$ cells/ $\mathrm{mL}$ in Brazil (Ruegg and Pantoja, 2013). Our study revealed that $66.36 \%$ and $31.78 \%$ of the examined BTM samples complied to the requirements of the Egyptian $\left(\mathrm{SCC}\right.$ not $\left.>750 \times 10^{3}\right)$ and the European specifications (SCC not $\left.>400 \times 10^{3}\right)$, respectively.

The high SCC of the examined BTM samples may be attributed to the stage of lactation, prevalence of subclinical mastitis and/or seasonal variation (Ruegg and Pantoja, 2013). The increased milk SCC may lead to reduction in milk yield, short shelf life of liquid milk, higher levels of proteolytic and lipolytic enzymes, altering the manufacturing properties of milk as reducing cheese yield and affecting the shelf life of dairy products (Olechnowicz and Jaśkowski, 2012).

The increased competitions between dairy companies encourage farms to produce high quality raw milk, as the dairy companies impose system of financial penalty if the SCC of bulk milk rises above a certain threshold and also offer 'bonus payments' if the SSC is under 200,000 or $250,000 / \mathrm{ml}$. Other companies do not rely on SCC only but also set quality standards based on the bacterial counts of BTM (Blowey and Edmondson, 2010).

The Aerobic Plate Count (APC) is considered an indicator of the general hygienic condition in the dairy farm and the health state of the udder (Olatoye et al.,2018). The obtained results of APC of the examined BTM were nearly similar to that recorded by Olatoye et al., 2018, lower counts were recorded by (Elmoslemany et al., 2016), while higher APC was recorded by (Naing et al., 2019; Kupradit et al., 2020). Aerobic Plate Count less than $5,000 \mathrm{cfu} / \mathrm{mL}$ of BTM is considered as an index of proper hygiene. The high APC of the examined BTM samples considered a bad indication revealed low hygiene and poor quality milk. Therefore, many processors provide incentive programs to encourage dairy farmers to produce milk with lower APC and SCC than the required regulatory limits (Olatoye et al., 2018).

Milk secreted from a healthy udder contains only a very few bacteria of about 500 to 1,000 per milliliter. The main sources of milk contamination include infected udder and/or teats, animal skin, faecal soiling of the udder, contaminated milking and storage equipment, and water used for cleaning (Pandey and Voskuil, 2011). The wide diversity of sources of contamination of raw milk diminishes the accuracy of APC in identifying the contamination sources. Therefore, using APC to evaluate the hygienic quality of milk is recommended to be accompanied by counting of specific groups of microorganisms such as $S$. aureus, coliform and B. cereus (Macedo et al., 2018).

The coliform group of bacteria comprises all aerobic and facultative anaerobic, gram-negative, non-spore forming rods able to ferment lactose with production of acid and gas at $32^{\circ} \mathrm{C}$ within $48 \mathrm{hr}$ (Hogan and Smith, 2003). Our results showed contamination of all examined BTM with coliforms, which parallel to the results obtained by Kunda et al., 2015, Comparatively higher results were recorded by (Ombarak and Elbagory, 2015) and (Naing et al., 2019); while, lower results were recorded by (Olatoye et al., 2018).

Coliforms are commonly found in the feces of cows and widely distributed in the farm environment. Therefore, coliform count reflects the hygienic and sanitation practices tracked on the farm, high coliform count of BTM indicates fecal contamination and unhygienic milk production practices. Consequently, it can result in milk spoilage and severe human diseases (Macedo et al., 2018). Likewise, contamination of milk with $E$. coli often reflects fecal contamination; it is the known causative agent of diarrhea and other foodborne-related illnesses through the ingestion of contaminated foodstuffs (Mohamed et al., 2017).

Our study revealed the contamination of examined BTM samples with $E$. coli with percentage of $32.24 \%$, which were analogous to the results documented by $\mathrm{Bi}$ et al. (2016), while, higher incidences were given by (Kupradit et al., 2020; El-Leboudy et al., 2014) failed to detect $E$. coli in BTM samples. E. coli has a zoonotic importance, as it is responsible for serious fatalities and milk borne disease outbreaks worldwide, and it is a major mastitis pathogen in dairy animals. The Antimicrobial resistance among some commensal $E$. coli strains isolated from cattle can be associated with the presence of virulence factors which is of a major public health risk with the introduction of these bacteria to the food chain (Fahim et al., 2019).

Staphylococci are normal inhabitants of skin and mucosa of healthy human and animals, the organisms are important agent of bovine mastitis, leading to economic damage to dairy farms. Staphylococcus aureus is regarded as a zoonotic pathogen implicated in both clinical medicine and food safety, it was isolated from animal body surfaces, hands of the milking operators, as well as from several dairy utensils, especially teat cups (Azevedo et al., 2016; Fisher and Paterson, 2020). The analyzed BTM contained S. aureus with incidence of $19.16 \%$, that is nearly similar to the incidence reported by Moheebi-Fani et al. (2016), 
whereas, higher incidences were recorded by Kupradit et al. (2020) and Zecconi et al. (2020).

Staphylococcus aureus is a major problem of public health causing food borne outbreaks. It produces many extracellular proteins and toxins (Mohamed et al., 2016). The produced enterotoxins are resistant to inactivation by gastrointestinal proteases and show thermal stability, making their elimination difficult to achieve, (Schelin et al., 2011). Staphylococcus aureus food borne illness can be caused by ingestion of as little as $20 \mathrm{ng}$ of enterotoxin that obtained from $S$. aureus count of $10^{5} \mathrm{cfu} / \mathrm{ml}$ (Hassan et al., 2015). Therefore, determination of $S$. aureus count is critical for risk management and surveillance in the field of food safety.

It is clear from the obtained results that $17.76 \%$ and $12.15 \%$ of the examined BTM contained S. aureus count $>100$ and $>500 \mathrm{cfu} / \mathrm{ml}$, respectively, and disagree with the Egyptian and European standards. Nearly similar S. aureus counts were recorded by Kupradit et al. (2020), lower count was reported by El-Leboudy et al. (2014), while higher counts were reported by Ombarak and Elbagory (2015).

Coagulase Negative Staphylococci (CNS) were detected in the examined BTM samples with high incidence, which may represent food safety risk. Coagulase Negative Staphylococci contaminate bulk milk through milking of mastitis animals or from the surrounding environment (NMC, 2016). Coagulase Negative Staphylococci are potential zoonotic pathogens, as a relatively high percentage of CNS strains possess enterotoxin genes making them able to produce enterotoxins in food (Oliveira et al., 2011). On the other hand, CNS are considered emerging mastitis pathogens, with a small SCC contribution for bulk milk (Azevedo et al., 2016).

Bacillus cereus is ubiquitous and found in soils, water, dust, plants, animals and humans. It was isolated from contaminated foods of both plant and animal origin. Contamination of animal teats with farm soil or faeces and milking equipment are the most important routes for introducing the organism into raw milk (Kupradit et al., 2020). Our findings recorded that $10.28 \%$ of the examined BTM samples were contaminated with high count of $B$. cereus that is not accepted by the Egyptian $(<1 \mathrm{cfu} / \mathrm{ml})$ and European $(<10 \mathrm{cfu} / \mathrm{ml})$ specifications. Our results were comparable to the results obtained by Kupradit et al. (2020). Higher incidences of B. cereus were given by Kassa et al. (2017).

Presence of $B$. cereus in raw milk considered as a potential threat due to its ability to form thermoduric endospores that are able to survive pasteurization, to grow and survive at refrigeration temperature and to produce toxins; in addition, it has the capacity to grow over a broad $\mathrm{pH}$ range of 4.9 to 9.3 (Cressey et al., 2016). In most B. cereus outbreaks, the number of the organism associated with diarrhea ranged from $10^{5}$ to $10^{8} \mathrm{cfu} / \mathrm{ml}$ of food (Chitov et al., 2008). This indicate that the count of B. cereus obtained in the present study was not high enough to cause illnesses.

Streptococci are important zoonotic pathogens, they are main causes of subclinical mastitis in dairy cattle and a source of economic losses for the dairy industry especially St. agalactiae, St. uberis and St. dysgalactiae. In human, streptococcal infections are associated with scarlet fever, sore-throat, tonsillitis, bacterial endocarditis, rheumatic fever and pneumonia (Youssef and Mohamed, 2015).

The current study revealed high incidence of streptococcal contamination of BTM, with the isolation of St. uberis from $21.50 \%$ of BTM samples, which was comparable to Asfour et al. (2016).

Contamination of BTM with environmental streptococci indicates poor hygiene during milking and improper cleaning and sanitation of equipment, in addition, the infected cows are a major source of St. uberis in milk. Therefore, control of streptococcal mastitis, specifically that caused by St. uberis and St. agalactiae, is recommended to improve the microbial quality of raw BTM (NMC, 2016).

\section{Correlation between SCC and Different} MICROBIAL PARAMETERS

Data obtained from this study show statistically significant positive correlations between SCC and APC, coliform, $S$. aureus and B. cereus count $(p<0.01)$; which approved by Pantoja et al. (2011), NMC (2016) and Olatoye et al. (2018). On contrary to our results, Moheebi-Fani et al. (2016) found no correlation between SCC and other bacterial parameters.

Considering the correlation between different bacteria; significant positive correlation was recorded between APC, coliform and $S$. aureus count $(p<0.05)$, which is in accordance with (Zadoks et al., 2004; Elmoslemany et al., 2016; Moheebi-Fani et al., 2016); while (Macedo et al., 2018; Olatoye et al., 2018) recorded weak correlation between APC and coliform and suggested that single quality parameters could not predict the others.

\section{Chemical parameters}

Results concerning the chemical analysis declared that all BTM samples agreed with the Egyptian specifications of raw cow milk, concerning fat \% (3\%) and SNF \% (8.25\%). Our findings declared statistically significant positive correlations between SCC and fat \% and ash \% ( $p<0.05)$, and no correlations were detected between SCC and other 
examined chemical parameters. Parallel observations were verified by (Moheebi-Fani et al., 2016; Macedo et al., 2018). On contrary to our results, El-Wakeel et al. (2010) found negative correlation between SCC and fat $(r=-0.302)$, lactose $(r=-0.525)$ and SNF $(r=-0.402)$, and a positive correlation between SCC and protein $(r=0.150)$. Jatawa et al. (2011) and Macedo et al. (2018) remarked negative correlation between SCC and protein, lactose and $\mathrm{SNF} \%$.

El-Tahawy and EL-Far (2010) observed a rise in plasmin levels in milk with high SCC which increases the breakdown of proteins, milk fat and other solids in milk, leading to a decrease in the levels of milk constituents. Jatawa et al. (2011) explained the increase in fat concentration in infected cows as not to be the result of increased synthesis, but due to a larger decrease in milk and lactose synthesis in comparative to fat.

Food quality assurance programs focus on producing milk with low somatic cell and bacterial count, resulting in better quality products with longer shelf life (Olech Nowicz and Jaśkowski, 2012).

\section{CONCLUSIONS AND RECOMMENDATIONS}

The obtained results revealed the relation between SCC and the microbial and chemical parameters of bulk tank milk of the examined dairy farms. High SCC and APC in most of examined farms indicate bad hygiene that was confirmed by the high coliform count, but $\mathrm{SCC} / \mathrm{ml}$ has a weak remarkable effect on the milk constituents. Most samples tested for milk quality parameters were below the acceptable limits suggested by legislations. The study showed high incidence of food poisoning bacteria (E. coli, $B$. cereus and $S$. aureus) which represent serious hazards to human health. Consequently, there is a need for improving the quality and ensuring the safety of bulk tank raw milk which can be achieved through application of Good Manufacturing Practices.

\section{NOVELTY STATEMENT}

This study provided an innovative data about the quality of bulk tank milk and declared the association between somatic cell count and the chemical constituents, microbiological profile and quality of bulk tank milk.

\section{AUTHOR'S CONTRIBUTION}

All authors shared the ideas and writing of the manuscript. Said S. Sallam and Mohamed A. El Shafaie were involved in planning and supervised the work. El Shaimaa N.
Mehany collected the samples and performed the bacteriological and chemical analysis. Karima M. Fahim contributed to the data analysis and interpretation. All authors discussed the results and contributed to the final version of the manuscript.

\section{CONFLICT OF INTEREST}

The authors have declared no conflict of interest.

\section{REFERENCES}

-Ahmed LI, Fahim KM (2018). Incidence of subclinical mastitis with special reference to lactate dehydrogenase (LDH) enzyme as a biomarker. Int. J. Dairy Sci., 13: 30-39. https:// doi.org/10.3923/ijds.2018.30.39

-Alhussien MN, Dang AK (2018). Milk somatic cells, factors influencing their release, future prospects, and practical utility in dairy animals: An overview. Vet. World, 11(5): 562-577. https://doi.org/10.14202/vetworld.2018.562-577

-APHA (2004). American Public Health Association. Standard methods for the examination of Dairy products, $17^{\text {th }}$. Ed. American Public Health Association. Washington D.C.

-Asfour HAE,Darwish SF,El-Wakeel SA (2016).Phenotypic and genotypic characterization of streptococcus uberis isolated from mastitic cow's milk. Assiut. Vet. Med. J., 62(151): 7183. https://doi.org/10.21608/avmj.2016.170009

-Azevedo C, Pacheco D, Soares L, Romão R, Moitoso M, Maldonado J, Guix R, Simões J (2016). Prevalence of contagious and environmental mastitis-causing bacteria in bulk tank milk and its relationships with milking practices of dairy cattle herds in São Miguel Island (Azores). Trop. Anim. Health Prod., 48: 451-459. https://doi.org/10.1007/ s11250-015-0973-6

-BAM "FDA's Bacteriological Analytical Manual" (2001). Staphylococcus aureus. Chapter12 in Bacteriological Analytical Manual. (on line) Food and Drug Administration (US FDA home page/CFSAN BAM).

-BAM "FDA's Bacteriological Analytical Manual" (2012). Bacillus cereus. Chapter 14 in Bacteriological Analytical Manual. (on line) Food and drug administration center for food safety and applied nutrition.

-BAM "FDA's Bacteriological Analytical Manual" (2013). Enumeration of Escherichia coli and the Coliform Bacteria. Chapter 4 in Bacteriological Analytical Manual (on line) Food and drug administration center for food safety and applied nutrition.

- Bi Y, Wang YJ, Qin Y, Guix Vallverdú R, Maldonado García J, Sun W (2016). Prevalence of bovine mastitis pathogens in bulk tank milk in China. PLoS One, 11(5): 13. https://doi. org/10.1371/journal.pone.0155621

- Blowey R, Edmondson P (2010). Mastitis control in dairy herds, $2^{\text {nd }}$ ed., CAB International, Wallingford, UK Butler Tanner and Dennis. https://doi.org/10.1079/9781845935504.0000

- Chitov T, Dispan R, Kasinrerk W (2008). Incidence and diarrhegenic potential of Bacillus cereus in pasteurized milk and cereal products in Thailand. J. Food Saf., 28: 467-481. https://doi.org/10.1111/j.1745-4565.2008.00125.x

- Cressey P, King N, Soboleva T (2016). Risk Profile: Bacillus cereus in dairy products. MPI Technical Paper No: 2016/58, New Zealand Government. Ministry for primary industry, http://www.mpi.govt.nz/news-and-resources/publications. 
- Egyptian Standards (2005). ES: 154-1/2005, Milk and Dairy products. PART: 1, Raw milk. Egyptian Organization for Standardization and Quality, Egypt.

-El-Leboudy AA, Amer AA, Abd El-Mohsen S (2014). Detection of some pathogenic organisms from dairy farm milk. Alex. J. Vet. Sci., 44(1): 111-118. https://doi. org/10.5455/ajvs.47762

-Elmoslemany AM, Almuhanna SF, Alnaeem AA (2016). Seasonal variations of raw milk hygienic quality in Saudi Arabia dairy herds. Alex. J. Vet. Sci., 49(2): 65-69. https:// doi.org/10.5455/ajvs.223487

-El-Tahawy AS, El-Far AH (2010). Influences of somatic cell count on milk composition and dairy farm profitability. Int. J. Dairy Technol., 63(3). https://doi.org/10.1111/j.14710307.2010.00597.x

-El-Wakeel SA, Asfour HAE, Gomaa AM (2010). The relationship between somatic cell count, milk constituents and pathogenic bacteria isolated from subclinical mastitis in dairy cows. J. Egypt. Vet. Med. Assoc., 70(4): 569-590.

-European Union (2004). Regulation (EC) No 853/2004 of the European Parliament and of the Council 29 April 2004 Laying down specific hygiene rules for food of animal origin.

- Fahim KM, Ismael E, Khalefa HS, Farag HS, Hamza DA (2019). Isolation and characterization of E. coli strains causing intramammary infections from dairy animals and wild birds. Int. J. Vet. Sci. Med., 7(1): 61-70. https://doi.org /10.1080/23144599.2019.1691378

- Fisher EA, Paterson GK (2020). Prevalence and characterization of methicillin-resistant staphylococci from bovine bulk tank milk in England and Wales. J. Glob. Antimicrob. Resist., https://doi.org/10.1016/j.jgar.2020.01.013

- Gillespie BE, Lewis MJ, Boonyayatra S, Maxwell ML, Saxton A, Oliver SP, Almeida RA (2012). Short communication: Evaluation of bulk tank milk microbiological quality of nine dairy farms in Tennessee. J. Dairy Sci., 95: 4275-4279. https://doi.org/10.3168/jds.2011-4881

- Hassan MG, Meshref MSA, Soad M Gomaa (2015). Microbiological quality and safety of fluid milk marketed in Cairo and Giza Governorates. Curr. Res. Dairy Sci., 7: 18-25. https://doi.org/10.3923/crds.2015.18.25

-Hogan JS, Smith KL (2003). Coliform mastitis. Vet. Res., 34: 507-519. https://doi.org/10.1051/vetres:2003022

-ISO (2003). ISO standard DIS 4833:2003 (E). Microbiology of food and feeding stuff/ Horizontal method for the enumeration of microorganisms/ colony count technique at $30^{\circ} \mathrm{C}$.

-Jatawa D, Koonawootrittriron S, Elzo MA, Suwanasopee T (2011). Bulk tank somatic cells and its relationship to milk production, milk composition, and revenue in dairy farms located in Central Thailand. Abstract T169. University of Florida, Gainesville, FL 32611- 0910, USA.

- Jayarao BM, Wolfgang DR (2003). Bulk tank milk analysis: A useful tool for improving milk quality and herd udder health. Vet. Clin. North Am. Food Anim. Pract., 19: 75-92. https://doi.org/10.1016/S0749-0720(02)00075-0

- Kassa A, Zewude G, Tessema ST (2017). Investigation on Bacillus cereus and associated risk factors in bovine raw milk in Debre Zeit town, Ethiopia. Revue Méd. Vét., 168, 10-12, 21: 213-218.

- Khodke MV, Bonde SW, Ambade RB (2009). Alteration of enzyme aspartate transaminase in goat milk related to udder health status. Vet. World, 2(1): 24-26.

-Kunda B, Pandey GS, Muma JB (2015). Compositional and sanitary quality of raw milk produced by smallholder dairy farmers in Lusaka Province of Zambia. Livest. Res. Rural Dev., 27(10): 2015.

-Kupradit C, Innok S, Woraratphoka J, Ketudat-cairns M (2020). Prevalence and characterization of pathogenic bacteria in bulk tank raw milk, Thailand. Walailak J. Sci. Tech., 17(6): 588-599. https://doi.org/10.48048/wjst.2020.4177

- Lindmark-Månsson H, Bränning C, Aldén G, Pauls-son M (2006). Relationship between somatic cell count, individual leukocyte populations and milk components in bovine udder quarter milk. Int. Dairy J., 16: 717-727. https://doi. org/10.1016/j.idairyj.2005.07.003

- Macedo SN, Gonçalves JL, Cortinhas CS, Leite RF, Santos MV (2018). Effect of somatic cell count on composition and hygiene indicators of bulk tank milk. Braz.J. Vet. Res. Anim. Sci., São Paulo, 55(1): 1-11. https://doi.org/10.11606/ issn.1678-4456.bjvras.2018.133413

- Mohamed AF, Fourreh AE, Okieh AA, Said CN, Mérito A, Yagi $S$ (2017). Evaluation of microbiological quality of raw milk from farmers and dairy producers in six districts of Djibouti. J. Food Microbiol. Saf. Hyg., 2: 124.

- Mohamed EY, Abdel-Rhman SH, Barwa R, El-Sokkary MA (2016). Studies on enterotoxins and antimicrobial resistance in staphylococcus aureus isolated from various sources. Adv. Microbiol., 6: 263-275. https://doi.org/10.4236/ aim.2016.64026

- Moheebi-Fani, M, Shekarforoush SS, Hosseinzadeh S, Ansari-Lari M, Mousavi-Davoodi M, Khorram R (2016). Discrepancies in evaluating farm management routines as risk factors of raw milk and udder hygiene in selected dairy farms of Fars province, Iran. J. Fac. Vet. Med. Istanbul Univ., 42(2): 138-149. https://doi.org/10.16988/iuvfd.2016.39707

- Naas HT, Zurghani MM, Garbaj AM, Azwai SM, Eshamah HL, Gammoudi FT, Abolghait SK, Moawad AA, Barbieri I, Eldaghayes IM (2018). Bacillus cereus an emerging public health concern in Libya: Isolation and antibiogram from food of animal origin. Libyan J. Med. Sci., 2: 56-61. https:// doi.org/10.4103/LJMS.LJMS_5_18

- Naing YW, Wai SS, Lin TN, Thu WP, Htun LL, Bawm S, Myaing TT (2019). Bacterial content and associated risk factors influencing the quality of bulk tank milk collected from dairy cattle farms in Mandalay Region. Food Sci. Nutr., 7: 1063-1071. https://doi.org/10.1002/fsn3.945

- National Mastitis Council (2016). Using bulk tank milk cultures in a dairy practice, national mastitis council fact sheet.

- Olatoye O, Amosun A, Ogbu U, (2018). Bulk tank somatic cell count and associated microbial quality of milk from selected dairy cattle herds in Oyo State, Nigeria. Ital. J. Food Saf., 7: 7130. https://doi.org/10.4081/ijfs.2018.7130

- Olechnowicz J, Jaśkowski JM (2012). Somatic cells count in cow's bulk tank milk. J. Vet. Med. Sci., 74(6): 681-668. https://doi.org/10.1292/jvms.11-0506

- Oliveira AM, Padovani CR, Miya NT, Sant'Ana AS, Pereira JL (2011). High incidence of enterotoxin D producing Staphylococcus spp. in Brazilian cow's raw milk and its relation with coagulase and thermonuclease enzymes. Foodborne Pathog. Dis., 8: 159-163. https://doi.org/10.1089/ fpd.2010.0590

- Ombarak RA, Elbagory AM (2015). Bacteriological quality and safety of raw cow's and buffalo's milk sold in Menoufia Governorate, Egypt. Minufiya Vet. J., 9: 101-113. https:// doi.org/10.21608/jcvr.2015.34836

- Pandey GS, Voskuil GCS (2011). Manual on Milk safety, 
quality and hygiene for dairy extension workers and dairy farmers. Golden Valley Agric. Res. Trust, Lusaka, Zambia, 7(26): 52.

- Pantoja JCF, Reinemann DJ, Ruegg PL (2011). Factors associated with coliform count in unpasteurized bulk milk. J. Dairy Sci., 94(6): 2680-2691. https://doi.org/10.3168/ jds.2010-3721

- Quinn PJ, Markey BK, Leonard FC, FitzPatrick ES, Fanning S, Hartigan PJ (2011). Veterinary Microbiology and Microbial Disease. $2^{\text {nd }}$ ed., Wiley-Blackwell, J Wiley and Sons Ltd Publication, UK.

- Ruegg PL, Pantoja JCF (2013). Understanding and using somatic cell counts to improve milk quality. Irish J. Agric. Food Res., 52: 101-117.

- Sarkar S (2016). microbiological quality of raw milk. J. Food Nutr. Diet., 1(2): 105.

-Schelin J, Wallin-Carlquist N, Cohn MT, Lindqvist R, Barker GC, Rådström P (2011). The formation of Staphylococcus aureus enterotoxin in food environments and advances in risk assessment. Virulence, 2: 580-592. https://doi.org/10.4161/ viru.2.6.18122

- Solanki KS, Parmar BC, Brahmbhatt MN, Nayak JB, Begadiya HB (2019). Cultural and biochemical characterization of B. cereus isolates and multidrug resistant detection of $\mathrm{B}$. cereus isolates collected from various chicken shops of market in and around Anand, Gujarat, India. Int. J. Curr. Microbiol. App. Sci., 8(3): 910-915. https://doi.org/10.20546/ ijcmas.2019.803.108

- Torky HA, Abu Tabeikh SM (2016). Incidence of coagulase negative staphylococcus isolated from mastitis cows and human contact. Alex.J. Vet. Sci., 51(2): 112-117. https://doi. org/10.5455/ajvs.204220

-Van Hooijdonk T, Hettinga K (2015). Dairy in a sustainable diet: A question of balance. Nutr. Rev., 73: 48. https://doi. org/10.1093/nutrit/nuv040

-Whitman WB, Paul DV, George MG, Dorothy J, Noel RK, Wolfgang L, Fred AR, Karl-Heinz S (2009). Bergey's manual of systematic bacteriology: The Firmicutes, $2^{\text {nd }} \mathrm{Ed}$. Vol. 3, Springer Dordrecht Heidelberg London New York, pp. 392- 420.

-Youssef AI,Mohamed SE (2015). Raw milk as a potential source of some zoonotic bacterial diseases in Ismailia, Egypt. Glob. Vet., 14(6): 824-829.

-Zadoks RN, González RN, Boor KJ, Schukken YH (2004). Mastitis-causing Streptococci are important contributors to bacterial counts in raw bulk tank milk. J. Food Prot., 67(12): 2644-2650. https://doi.org/10.4315/0362$028 \mathrm{X}-67.12 .2644$

-Zecconi A, Casirani G, Binda E, Piccinini R (2002). The importance to assess the effects of voluntary milking system on teat tissues, intramammary infections and somatic cell counts. Dept. Anim. Path-infect. Dis. Lab., University of Mailan. Delaval Hygiene, Technology center, Inaugal symposium. https://doi.org/10.4081/ijas.2003.275

-Zecconi A, dell'Orco F, Rizzi N, Vairani, D, Cipolla M, Pozzi P, Zanini L (2020). Cross-sectional study on the prevalence of contagious pathogens in bulk tank milk and their effects on somatic cell counts and milk yield. Ital. J. Anim. Sci., 19(1): 66-74. https://doi.org/10.1080/1828051X.2019.1693282 